\title{
Outcomes After Radiotherapy Alone for Metastatic Spinal Cord Compression in Patients with Oligo-metastatic Breast Cancer
}

\author{
DIRK RADES ${ }^{1}$, ANNIKA PANZNER ${ }^{1}$, STEFAN JANSSEN $^{1,2}$, JUERGEN DUNST $^{3}$, \\ THEO VENINGA ${ }^{4}$, NIELS H. HOLLÄNDER ${ }^{5}$ and STEVEN E. SCHILD ${ }^{6}$ \\ ${ }^{1}$ Department of Radiation Oncology, University of Lübeck, Lübeck, Germany; \\ ${ }^{2}$ Medical Practice of Radiotherapy and Radiation Oncology, Hannover, Germany; \\ ${ }^{3}$ Department of Radiation Oncology, University of Kiel, Kiel, Germany; \\ ${ }^{4}$ Department of Radiotherapy, Dr. Bernard Verbeeten Institute, Tilburg, Netherlands; \\ ${ }^{5}$ Department of Oncology and Palliative Units, Zealand University Hospital, Naestved, Denmark; \\ ${ }^{6}$ Department of Radiation Oncology, Mayo Clinic, Scottsdale, AZ, U.S.A.
}

\begin{abstract}
Background/Aim: Patients with oligo-metastatic breast cancer are a unique patient subgroup with more favourable outlook than most patients with metastatic disease. Prognostic factors in these patients with metastatic spinal cord compression (MSCC) were evaluated. Patients and Methods: In 159 patients irradiated for MSCC from oligo-metastatic breast cancer, seven characteristics were retrospectively analyzed including age, interval between breast cancer diagnosis and irradiation of MSCC, time developing motor deficits, ambulatory status, involved vertebrae, performance score (ECOG-PS) and radiotherapy regimen. Results: Improvement of motor function was significantly associated with time developing motor deficits $(p=0.017)$, post-radiotherapy ambulatory status with preradiotherapy ambulation $(p=0.012)$ and ECOG-PS $1-2$ $(p=0.029)$. Radiation doses of 39-40 Gy (equivalent doses) resulted in 1- and 2-year local control of 100\% and 95\%. On multivariate analyses, higher doses were associated with local control $(p=0.011)$. Pre-radiotherapy ambulatory status $(p=0.001)$ and ECOG-PS 1-2 ( $p=0.002)$ were associated with survival. Conclusion: Significant prognostic factors were identified for patients with MSCC from oligo-metastatic breast cancer. Higher radiation doses improved local control.
\end{abstract}

Correspondence to: Dirk Rades, MD, Department of Radiation Oncology, University of Lübeck, Lübeck, Ratzeburger Allee 160, 23562 Lübeck, Germany. Tel: +49 45150045401, Fax: +49 45150045404, e-mail: Rades.Dirk@gmx.net

Key Words: Breast cancer, oligo-metastatic disease, metastatic spinal cord compression, irradiation, response, local control, survival.
Patients with oligo-metastatic disease should be considered a unique group of cancer patients, since they generally have more favourable prognoses than most patients with multiple metastases (1-12). Patients with oligo-metastatic disease may benefit from more intensive treatments (13). However, the risk of long-term toxicity is an important consideration since these patients may live for several years and the risk of late treatment-related toxicity increases with time. This is especially important for breast cancer patients (8-12). Unfortunately, breast cancer patients often develop bone metastases during their lifetime (14). If bone metastases develop in the vertebral column, they may lead to spinal cord compression, causing severe pain and neurological deficits $(15,16)$. True metastatic spinal cord compression (MSCC) is defined as a state characterized with neurologic (mainly motor) deficits; epidural disease alone is impending MSCC (16). Excellent outcomes can be achieved with radiotherapy alone based on the findings of a previous retrospective study of patients with MSCC and oligo-metastatic disease (17). This previous study included patients with many different primary tumour types and investigated several characteristics including the type of primary tumour for potential associations with outcomes. During the last decade, it has been increasingly important to specifically examine single tumour entities, because they vary in biological behaviour, survival and sensitivity to radiotherapy and systemic treatment $(16,18-23)$. Therefore, this study of patients with MSCC and oligo-metastatic disease focused on a single tumour entity, i.e. breast cancer.

\section{Patients and Methods}

The data of 159 female patients irradiated for MSCC from oligometastatic breast cancer between 1996 and 2017 were retrospectively analyzed for treatment outcomes in terms of improvement of motor 
deficits, overall response (OR) to radiotherapy, ability to walk following irradiation, local control of MSCC and overall survival (OS). Oligo-metastatic disease was defined as involvement by MSCC of only one to four vertebrae but no other bone or visceral metastases. The outcomes were evaluated for potential associations with seven characteristics including age $(\leq 60 \mathrm{vs} . \geq 61$ years, median $=60$ years), interval from diagnosis of breast cancer until irradiation of MSCC ( $\leq 15 v s .>15$ months (24)), time developing motor deficits before radiotherapy was started ( $\leq 7 \mathrm{vs.}$. 8-14 vs. $>14$ days (25)), ambulatory status prior to irradiation (not ambulatory $v s$. ambulatory), number of vertebrae affected by MSCC (1-2 vs. 3-4 (24)), Eastern Cooperative Oncology Group (ECOG) performance score at the start of radiotherapy (ECOG 1-2 vs. ECOG 3-4), and the radiotherapy regimen. The most commonly used regimen (10x3 Gy in 2 weeks) was compared to lower $(1 \times 8 \mathrm{~Gy}$ and $5 \times 4 \mathrm{~Gy})$ and higher doses $(15 \times 2.5$ Gy and $20 \times 2$ Gy). The equivalent doses in $2 \mathrm{~Gy}$ fractions (EQD2) with respect to tumour cell kill (using an $\alpha / \beta$-ratio of $10 \mathrm{~Gy}$ ) of these five regimens were $12.0 \mathrm{~Gy}$ ( $1 \times 8 \mathrm{~Gy}), 23.3 \mathrm{~Gy}$ $(5 \times 4$ Gy), 32.5 Gy $(10 \times 3$ Gy), 39.1 Gy $(15 \times 2.5 \mathrm{~Gy})$ and $40.0 \mathrm{~Gy}$ $(20 \times 2$ Gy), respectively (26).

Motor function was evaluated directly before the start of radiation treatment (pre-radiotherapy), and directly after the last radiation session, at 1 month, 3 months and 6 months following radiotherapy. It was assessed by using the following classification: $0=$ normal strength, 1 =patient able to walk without aid, 2=patient able to walk, aid (walling stick, clutches, rollator) required, $3=$ patient not able to walk, $4=$ patient completely paraplegic (27). For improvement and deterioration of motor deficits, a change by one or more categories was required to be considered a change.

For improvement of motor function, the best response to radiotherapy during the follow up of up to 6 months was considered. OR was defined as improvement or at least, no further progression of motor deficits following irradiation. For OR, the best response during the follow up was recorded. For the analyses of improvement of motor function and of OR, the chi-square test was used. This test was also applied for the analyses of post-radiotherapy ambulatory status. In these analyses, $p$-values of less than 0.05 were considered significant, and $p$-values greater than 0.05 and less than 0.10 were considered representing a trend.

For the univariate analyses of local control of MSCC and OS rates (both referenced from the start date of radiotherapy), the Kaplan-Meier method was applied (28), and the corresponding Kaplan-Meier curves were compared with the log-rank test. Those patients who experienced deterioration of their motor deficits during radiotherapy were excluded from the analyses of local control. The characteristics that were significant or showed a trend on univariate analyses were further evaluated in a multivariate manner with Cox proportional hazard model.

\section{Results}

Median follow-up times were 14 months (range=3-64 months) for the entire cohort and 15 months (range=6-64 months) for those patients who were alive at last follow-up.

Improvement of motor function by at least one category was observed in 49 out of 159 patients $(31 \%)$ and was significantly associated with the time developing motor deficits prior to radiation therapy ( $p=0.017$ ) (Table I). The OR rate in the whole series was $95 \%$ (151 out of 159
Table I. Improvement of motor deficits following radiotherapy $(R T)$.

\begin{tabular}{|c|c|c|}
\hline & $\begin{array}{c}\text { Improvement } \\
\mathrm{N}(\%)\end{array}$ & $p$-Value \\
\hline \multicolumn{3}{|l|}{ Age } \\
\hline$\leq 60$ Years $(\mathrm{N}=80)$ & $30(38)$ & \multirow[t]{2}{*}{0.130} \\
\hline$\geq 61$ Years $(\mathrm{N}=79)$ & $19(24)$ & \\
\hline \multicolumn{3}{|c|}{ Interval from diagnosis of $\mathrm{BC}$ to $\mathrm{RT}$} \\
\hline$\leq 15$ Months $(\mathrm{N}=38)$ & $8(21)$ & \multirow[t]{2}{*}{0.215} \\
\hline >15 Months $(\mathrm{N}=121)$ & $41(34)$ & \\
\hline \multicolumn{3}{|l|}{ Time developing motor deficits } \\
\hline$\leq 7$ Days $(N=16)$ & $1(6)$ & \multirow[t]{3}{*}{0.017} \\
\hline 8-14 Days $(N=40)$ & $7(18)$ & \\
\hline >14 Days $(\mathrm{N}=103)$ & $41(40)$ & \\
\hline \multicolumn{3}{|l|}{ Ambulatory status pre-RT } \\
\hline Not ambulatory $(\mathrm{N}=18)$ & $7(39)$ & \multirow[t]{2}{*}{0.497} \\
\hline Ambulatory $(\mathrm{N}=141)$ & $42(30)$ & \\
\hline \multicolumn{3}{|l|}{ Number of involved vertebrae } \\
\hline $1-2(\mathrm{~N}=132)$ & $41(31)$ & \multirow[t]{2}{*}{0.909} \\
\hline $3-4(\mathrm{~N}=27)$ & $8(30)$ & \\
\hline \multicolumn{3}{|l|}{ ECOG performance score } \\
\hline $1-2(N=140)$ & $42(30)$ & \multirow[t]{2}{*}{0.629} \\
\hline $3-4(\mathrm{~N}=19)$ & $7(37)$ & \\
\hline \multicolumn{3}{|l|}{ Radiotherapy regimen } \\
\hline $1 \times 8 \mathrm{~Gy} / 5 \times 4$ Gy $(\mathrm{N}=60)$ & $17(28)$ & \multirow[t]{3}{*}{0.510} \\
\hline $10 \times 3$ Gy $(\mathrm{N}=40)$ & $10(25)$ & \\
\hline $15 \times 2.5 \mathrm{~Gy} / 20 \times 2$ Gy $(\mathrm{N}=59)$ & $22(37)$ & \\
\hline Entire cohort & $49(31)$ & \\
\hline
\end{tabular}

ECOG: Eastern Cooperative Oncology Group; BC: breast cancer. Bold indicates significant $p$-Values.

patients), and a significant association with any of the investigated characteristics was not found (Table II). Following radiotherapy, 147 of the 159 patients (92\%) were able to walk, of whom 119 patients $(75 \%)$ had either normal strength or were ambulatory without aid. Of those 18 patients who were not ambulatory prior to irradiation, 7 patients (39\%) regained ambulatory status, and 140 of 141 ambulatory patients maintained ambulation. Postradiotherapy ambulatory status was significantly associated with pre-radiotherapy ambulatory status $(p=0.012)$ and an ECOG performance score of 1-2 ( $p=0.029)$ (Table III).

Local control rates of MSCC were $98 \%, 96 \%, 91 \%$ and $87 \%$, respectively, at $6,12,18$ and 24 months for the entire cohort. On univariate analyses of local control (Table IV), the radiotherapy regimen had a significant impact on outcome favouring higher doses $(p=0.018$, Figure 1). Patients receiving $15 \times 2.5$ Gy or $20 \times 2$ Gy had local control rates of $100 \%$ up to 18 months and still $95 \%$ at 24 months. In addition, a trend towards improved local control was found for patients ambulatory prior to irradiation $(p=0.094)$ and those with involvement by MSCC of only 1-2 vertebrae $(p=0.056)$. In the multivariate analysis, higher radiation doses maintained significance (hazard ratio $(\mathrm{HR})=1.65,95 \%$ 
Table II. Overall response to radiotherapy $(R T)$.

\begin{tabular}{|c|c|c|}
\hline & $\begin{array}{c}\text { Overall response } \\
\mathrm{N}(\%)\end{array}$ & $p$-Value \\
\hline \multicolumn{3}{|l|}{ Age } \\
\hline$\leq 60$ Years $(\mathrm{N}=80)$ & $76(95)$ & \multirow[t]{2}{*}{0.996} \\
\hline$\geq 61$ Years $(\mathrm{N}=79)$ & $75(95)$ & \\
\hline \multicolumn{3}{|c|}{ Interval from diagnosis of $\mathrm{BC}$ to $\mathrm{RT}$} \\
\hline$\leq 15$ Months $(\mathrm{N}=38)$ & $33(87)$ & \multirow[t]{2}{*}{0.554} \\
\hline$>15$ Months $(\mathrm{N}=121)$ & $118(98)$ & \\
\hline \multicolumn{3}{|l|}{ Time developing motor deficits } \\
\hline$\leq 7$ Days $(\mathrm{N}=16)$ & $11(69)$ & \multirow[t]{3}{*}{0.481} \\
\hline 8-14 Days $(\mathrm{N}=40)$ & $37(92)$ & \\
\hline$>14$ Days $(\mathrm{N}=103)$ & $103(100)$ & \\
\hline \multicolumn{3}{|l|}{ Ambulatory status pre-RT } \\
\hline Not ambulatory $(\mathrm{N}=18)$ & $15(83)$ & \multirow[t]{2}{*}{0.590} \\
\hline Ambulatory $(\mathrm{N}=141)$ & $136(96)$ & \\
\hline \multicolumn{3}{|l|}{ Number of involved vertebrae } \\
\hline $1-2(\mathrm{~N}=132)$ & $128(97)$ & \multirow[t]{2}{*}{0.573} \\
\hline $3-4(\mathrm{~N}=27)$ & $23(85)$ & \\
\hline \multicolumn{3}{|l|}{ ECOG performance score } \\
\hline $1-2(N=140)$ & $135(96)$ & \multirow[t]{2}{*}{0.615} \\
\hline $3-4(\mathrm{~N}=19)$ & $16(84)$ & \\
\hline \multicolumn{3}{|l|}{ Radiotherapy regimen } \\
\hline $1 \times 8 \mathrm{~Gy} / 5 \times 4$ Gy $(\mathrm{N}=60)$ & $56(93)$ & \multirow[t]{4}{*}{0.932} \\
\hline $10 \times 3$ Gy $(\mathrm{N}=40)$ & $40(100)$ & \\
\hline $15 \times 2.5 \mathrm{~Gy} / 20 \times 2$ Gy $(\mathrm{N}=59)$ & $55(93)$ & \\
\hline Entire cohort & $151(95)$ & \\
\hline
\end{tabular}

ECOG: Eastern Cooperative Oncology Group; BC: breast cancer.
Table III. Ambulatory rates following radiotherapy (RT) of metastatic spinal cord compression.

\begin{tabular}{|c|c|c|}
\hline & $\begin{array}{c}\text { Ambulatory } \\
\mathrm{N}(\%)\end{array}$ & $\mathrm{p}$-Value \\
\hline \multicolumn{3}{|l|}{ Age } \\
\hline$\leq 60$ Years $(\mathrm{N}=80)$ & $74(93)$ & 0.994 \\
\hline$\geq 61$ Years $(\mathrm{N}=79)$ & $73(92)$ & \\
\hline \multicolumn{3}{|c|}{ Interval from diagnosis of $\mathrm{BC}$ to $\mathrm{RT}$} \\
\hline$\leq 15$ Months $(\mathrm{N}=38)$ & $29(76)$ & 0.238 \\
\hline$>15$ Months $(\mathrm{N}=121)$ & $118(98)$ & \\
\hline \multicolumn{3}{|l|}{ Time developing motor deficits } \\
\hline$\leq 7$ Days $(\mathrm{N}=16)$ & $11(69)$ & 0.426 \\
\hline 8-14 Days $(\mathrm{N}=40)$ & $34(85)$ & \\
\hline >14 Days $(\mathrm{N}=103)$ & $102(99)$ & \\
\hline \multicolumn{3}{|l|}{ Ambulatory status pre-RT } \\
\hline Not ambulatory $(\mathrm{N}=18)$ & 7 (39) & 0.012 \\
\hline Ambulatory $(\mathrm{N}=141)$ & $140(99)$ & \\
\hline \multicolumn{3}{|l|}{ Number of involved vertebrae } \\
\hline $1-2(\mathrm{~N}=132)$ & $123(93)$ & 0.826 \\
\hline $3-4(\mathrm{~N}=27)$ & $24(89)$ & \\
\hline \multicolumn{3}{|l|}{ ECOG performance score } \\
\hline $1-2(\mathrm{~N}=140)$ & $138(99)$ & 0.029 \\
\hline $3-4(\mathrm{~N}=19)$ & $9(47)$ & \\
\hline \multicolumn{3}{|l|}{ Radiotherapy regimen } \\
\hline $1 \times 8$ Gy/5×4 Gy $(\mathrm{N}=60)$ & $53(88)$ & 0.893 \\
\hline $10 \times 3$ Gy $(\mathrm{N}=40)$ & $37(93)$ & \\
\hline $15 \times 2.5 \mathrm{~Gy} / 20 \times 2 \mathrm{~Gy}(\mathrm{~N}=59)$ & $57(97)$ & \\
\hline Entire cohort & $147(92)$ & \\
\hline
\end{tabular}

ECOG: Eastern Cooperative Oncology Group; BC: breast cancer. Bold indicates significant $p$-Values.

of MSCC $(\mathrm{HR}=1.28,95 \% \mathrm{CI}=0.81-2.00, p=0.288)$, the time developing motor deficits $(\mathrm{HR}=1.34,95 \% \mathrm{CI}=0.79-2.22$, $p=0.273)$, and the number of involved vertebrae $(\mathrm{HR}=1.20$, $95 \% \mathrm{CI}=0.75-1.90, p=0.437)$ did not reach significance in the multivariate analysis.

\section{Discussion}

The present study focused specifically on patients with MSCC from oligo-metastatic breast cancer. In the entire cohort, 95\% of patients responded to radiotherapy, and $31 \%$ showed improvement of motor deficits. Furthermore, $92 \%$ of the patients were ambulatory following radiotherapy. When compared to a previous study of 504 patients with MSCC from breast cancer that included patients with oligo-metastatic disease and multiple metastases, OR and improvement rates were quite similar (18). In that study, $90 \%$ of the patients responded to radiotherapy, and $34 \%$ showed improvement. Furthermore, local control rates of MSCC at 1 year and 2 years were quite high at $96 \%$ and $87 \%$. The corresponding local control rates in our previous study, (18) were a bit lower, i.e. $90 \%$ and $83 \%$. In both studies, local control of MSCC was significantly associated with higher radiation doses. In the 
Table IV. Local control of metastatic spinal cord compression (MSCC) at 3, 6, 9 and 12 months (mos.) following radiotherapy (RT). These analyses were performed in the 151 patients who responded to RT.

\begin{tabular}{|c|c|c|c|c|c|}
\hline & 6 Mos. (\%) & 12 Mos. (\%) & 18 Mos. $(\%)$ & 24 Mos. (\%) & $p$-Value \\
\hline \multicolumn{6}{|l|}{ Age } \\
\hline$\leq 60$ Years $(N=76)$ & 97 & 96 & 87 & 82 & \multirow[t]{2}{*}{0.199} \\
\hline$\geq 61$ Years $(\mathrm{N}=75)$ & 99 & 97 & 97 & 92 & \\
\hline \multicolumn{6}{|c|}{ Interval from diagnosis of $\mathrm{BC}$ to $\mathrm{RT}$} \\
\hline$\leq 15$ Months $(\mathrm{N}=33)$ & 94 & 94 & 94 & 94 & \multirow[t]{2}{*}{0.723} \\
\hline$>15$ Months $(\mathrm{N}=118)$ & 99 & 97 & 91 & 86 & \\
\hline \multicolumn{6}{|l|}{ Time developing motor deficits } \\
\hline$\leq 7$ Days $(\mathrm{N}=11)$ & 91 & 91 & 91 & n.a. & \multirow[t]{3}{*}{0.746} \\
\hline 8-14 Days $(\mathrm{N}=37)$ & 97 & 94 & 94 & 94 & \\
\hline >14 Days $(\mathrm{N}=103)$ & 99 & 98 & 91 & 85 & \\
\hline \multicolumn{6}{|l|}{ Ambulatory status pre-RT } \\
\hline Not ambulatory $(\mathrm{N}=15)$ & 87 & 87 & 87 & 87 & \multirow[t]{2}{*}{0.094} \\
\hline Ambulatory $(\mathrm{N}=136)$ & 99 & 98 & 92 & 87 & \\
\hline \multicolumn{6}{|l|}{ Number of involved vertebrae } \\
\hline $1-2(\mathrm{~N}=128)$ & 100 & 98 & 92 & 87 & \multirow[t]{2}{*}{0.056} \\
\hline $3-4(\mathrm{~N}=23)$ & 87 & 87 & 87 & 87 & \\
\hline \multicolumn{6}{|l|}{ ECOG performance score } \\
\hline $1-2(\mathrm{~N}=135)$ & 99 & 98 & 92 & 87 & \multirow[t]{2}{*}{0.117} \\
\hline $3-4(\mathrm{~N}=16)$ & 88 & 88 & 88 & 88 & \\
\hline \multicolumn{6}{|l|}{ Radiotherapy regimen } \\
\hline $1 \times 8 \mathrm{~Gy} / 5 \times 4$ Gy $(\mathrm{N}=56)$ & 95 & 93 & 80 & 80 & \multirow[t]{4}{*}{0.018} \\
\hline $10 \times 3$ Gy $(\mathrm{N}=40)$ & 100 & 97 & 91 & 82 & \\
\hline $15 \times 2.5 \mathrm{~Gy} / 20 \times 2 \mathrm{~Gy}(\mathrm{~N}=55)$ & 100 & 100 & 100 & 95 & \\
\hline Entire cohort & 98 & 96 & 91 & 87 & \\
\hline
\end{tabular}

ECOG: Eastern Cooperative Oncology Group; BC: breast cancer; n.a.: not available. Bold indicates significant $p$-Values.

current study, the higher-dose regimens $15 \times 2.5$ Gy and $20 \times 2$ Gy resulted in 1- and 2-year local control rates of $100 \%$ and $95 \%$, respectively. These dose-regimens resulted in $13 \%$ better local control at 2 years compared to $10 \times 3 \mathrm{~Gy}$. In our previous study we reported that, the 1- and 2-year local control rates were $92 \%$ and $84 \%$, respectively, after longer-course radiotherapy with $10 \times 3$ Gy, $15 \times 2.5$ Gy or $20 \times 2$ Gy (18). The local control rates were also lower than those in the present study $(99 \%$ and $90 \%$, respectively), when the 10x3 Gy and the higher-dose groups were combined. Our results also showed that the 1- and 2-year OS rates were considerably higher than those reported in our previous study (81\% and $67 \%$ vs. $61 \%$ and $46 \%$ ) (18). When comparing the longer-course radiotherapy groups, the 1- and 2 -years OS rates in the present study were $86 \%$ and $81 \% \mathrm{vs}$. $64 \%$ and $52 \%$ in our previous study (18).

The results for the entire cohort of the present study were very similar to those found in a subgroup of breast cancer patients in a previous study of oligo-metastatic patients with MSCC from different primary tumour types treated between 1992 and 2005 (17). In that study, improvement of motor function and OR were reported for $33 \%$ and $94 \%$ of breast cancer patients. Local control rates at 1 and 2 years were $96 \%$ and $87 \%$, similar to the present study. OS rates at 1 and 2 years were $81 \%$ and $51 \%$. Thus, 2 -year OS was worse than in the present study, which most likely reflects the improvement of systemic treatment since 2005. In contrast to the current study, in our previous study (17) we did not particularly focus on breast cancer patients and did not investigate potential prognostic factors for treatment outcomes. Therefore, a comparison between the two studies with respect to prognostic factors is not possible.

The fact that higher radiation doses can result in improved local control has been previously reported in a matched-pair study of 382 patients with MSCC from different primary tumour types and favourable survival prognoses. Patients receiving $15 \times 2.5$ Gy or $20 \times 2$ Gy had a significantly better local control of MSCC than patients treated with $10 \times 3 \mathrm{~Gy}$ (29). The local control rates after 2 years were $92 \%$ and $71 \%$, respectively ( $p=0.012$ ). Moreover, the 2 -year OS rates were also significantly better in the higher doses group $(68 \%$ vs. 53\%, $p=0.013$ ). Both 2-year local control and OS were very similar when compared to the higher doses group $(15 \times 2.5 \mathrm{~Gy}$ or $20 \times 2 \mathrm{~Gy})$ of the present study, which were $87 \%$ and $67 \%$, respectively.

Taking into account the data from the present study and the available literature, patients with MSCC and favourable survival prognoses including breast cancer patients with oligo-metastatic disease appear to benefit from radiation 
Table V. Overall survival of patients (MSCC) at 3, 6, 9 and 12 months (mos.) following radiotherapy (RT) for metastatic spinal cord compression.

\begin{tabular}{|c|c|c|c|c|c|}
\hline & 6 Mos. $(\%)$ & 12 Mos. (\%) & 18 Mos. (\%) & 24 Mos. (\%) & $p$-Value \\
\hline \multicolumn{6}{|l|}{ Age } \\
\hline$\leq 60$ Years $(\mathrm{N}=80)$ & 93 & 81 & 81 & 61 & \multirow[t]{2}{*}{0.584} \\
\hline$\geq 61$ Years $(\mathrm{N}=79)$ & 95 & 82 & 78 & 78 & \\
\hline \multicolumn{6}{|c|}{ Interval from diagnosis of $\mathrm{BC}$ to $\mathrm{RT}$} \\
\hline$\leq 15$ Months $(\mathrm{N}=38)$ & 82 & 66 & 66 & 66 & \multirow[t]{2}{*}{0.002} \\
\hline$>15$ Months $(\mathrm{N}=121)$ & 98 & 86 & 84 & 70 & \\
\hline \multicolumn{6}{|l|}{ Time developing motor deficits } \\
\hline$\leq 7$ Days $(\mathrm{N}=16)$ & 75 & 53 & 53 & n.a. & \multirow[t]{3}{*}{0.002} \\
\hline 8-14 Days $(\mathrm{N}=40)$ & 88 & 74 & 74 & 74 & \\
\hline >14 Days $(\mathrm{N}=103)$ & 99 & 89 & 86 & 70 & \\
\hline \multicolumn{6}{|l|}{ Ambulatory status pre-RT } \\
\hline Not ambulatory $(\mathrm{N}=18)$ & 56 & 35 & 35 & 18 & \multirow[t]{2}{*}{$<0.001$} \\
\hline Ambulatory $(\mathrm{N}=141)$ & 99 & 87 & 85 & 74 & \\
\hline \multicolumn{6}{|l|}{ Number of involved vertebrae } \\
\hline $1-2(\mathrm{~N}=132)$ & 93 & 85 & 83 & 70 & \multirow[t]{2}{*}{0.005} \\
\hline $3-4(\mathrm{~N}=27)$ & 96 & 49 & 49 & 49 & \\
\hline \multicolumn{6}{|l|}{ ECOG performance score } \\
\hline $1-2(\mathrm{~N}=140)$ & 98 & 87 & 84 & 73 & \multirow[t]{2}{*}{$<0.001$} \\
\hline $3-4(\mathrm{~N}=19)$ & 63 & 43 & 43 & 21 & \\
\hline \multicolumn{6}{|l|}{ Radiotherapy regimen } \\
\hline 1x8 Gy/5x4 Gy $(\mathrm{N}=60)$ & 92 & 72 & 72 & 45 & \multirow[t]{4}{*}{0.011} \\
\hline $10 \times 3$ Gy $(\mathrm{N}=40)$ & 95 & 89 & 89 & 82 & \\
\hline $15 \times 2.5 \mathrm{~Gy} / 20 \times 2 \mathrm{~Gy}(\mathrm{~N}=59)$ & 95 & 85 & 80 & 80 & \\
\hline Entire cohort & 94 & 81 & 80 & 67 & \\
\hline
\end{tabular}

ECOG: Eastern Cooperative Oncology Group; BC: breast cancer; n.a.: not available. Bold indicates significant $p$-Values.

doses higher than 3 Gy in 10 fractions with significantly improved local control of $\operatorname{MSCC}(17,29)$. The primary limitation of the available studies is their retrospective design with inherent risks of including selection biases.

Regarding the EQD2 with respect to tumour cell kill, the dose-fractionation regimens $15 \times 2.5$ Gy and $20 \times 2$ Gy correspond to $39.1 \mathrm{~Gy}$ and $40.0 \mathrm{~Gy}$, respectively (26). When compared to $10 \times 3 \mathrm{~Gy}(\mathrm{EQD} 2=32.5 \mathrm{~Gy})$, these reflect dose escalations by $20 \%$ and $23 \%$, respectively. One may question whether dose escalation by more than $23 \%$ will further increase the local control of MSCC in patients with favourable prognoses, such as patients with oligo-metastatic breast cancer. This question would ideally be answered in a prospective trial. Furthermore, patients with favourable prognoses including those with MSCC from oligo-metastatic breast cancer who respond to radiotherapy may not require upfront decompressive surgery, which has been demonstrated in a randomised trial from 2005 to improve outcomes of selected patients with MSCC and has become increasingly popular since then (30). In that randomised trial of 101 patients with MSCC from different primary tumours, a relatively good performance status and an expected OS of at least 3 months, the ambulatory rate following surgery and radiotherapy was $84 \%$ (42 out of 50 patients), which was less than the $92 \%$ in the present cohort.

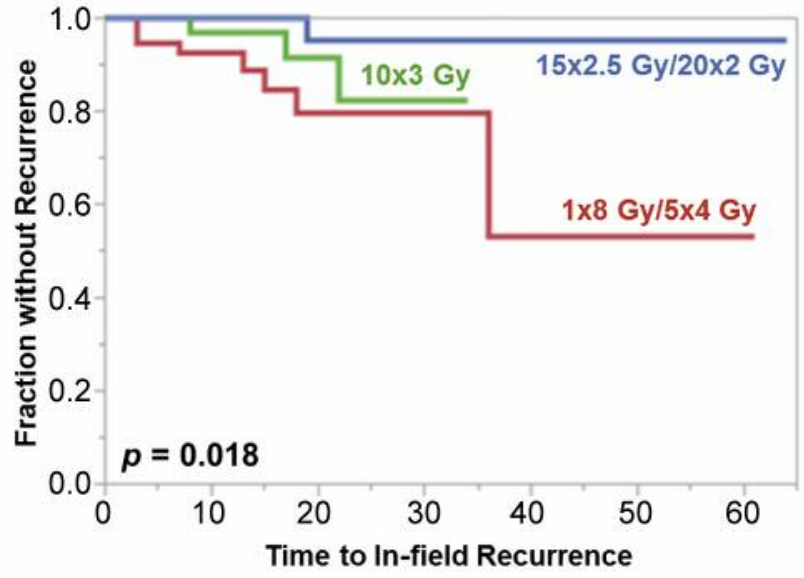

Figure 1. Kaplan-Meier curves of the three dose groups $1 \times 8 \mathrm{~Gy} / 5 \times 4 \mathrm{~Gy}$, $10 \times 3$ Gy and $15 \times 2.5$ Gy/20 $\times 2$ Gy with respect to local control of MSCC. The $p$-Value was calculated using the log-rank test.

In addition to the radiation dose for local control, other significant predictors were identified for improvement of motor function, post-radiotherapy ambulatory status and OS. These predictors were previously reported in studies focusing 
on MSCC from breast cancer and in studies of MSCC from different primary tumours $(16-19,24,15,31)$. As already stated in previous studies, these predictors can guide physicians when aiming to personalize the treatment for breast cancer patients with MSCC and oligo-metastatic disease.

In summary, significant prognostic factors were identified for different outcomes in patients with MSCC from oligometastatic breast cancer. Radiation regimens with an EQD2 of 39.1-40.0 Gy were associated with significantly better local control of MSCC and should be recommended for these patients. A prospective trial is required in order to examine whether an additional dose escalation will further increase the local control rates.

\section{Conflicts of Interest}

On behalf of all Authors, the corresponding Author states that there is no conflict of interest related to this study.

\section{Acknowledgements}

The study is part of the project InnoCan, funded by Interreg Deutschland-Denmark with funds from the European Regional Development Fund.

\section{References}

1 Palma DA, Louie AV and Rodrigues GB: New strategies in stereotactic radiotherapy for oligometastases. Clin Cancer Res 21: 5198-5204, 2015.

2 Bruni A, Gaito S, Ciarmatori A, Lanfranchi B, Mazzeo E, Maffei N, Giacobazzi P, Turco E, Guidi G and Bertoni F: Radiosurgery using tomotherapy for patients with brain oligo-metastasis: A retrospective analysis on feasibility and tolerance. Anticancer Res 35: 6805-6812, 2015.

3 Sharma A, Duijm M, Oomen-de Hoop E, Aerts JG, Verhoef C, Hoogeman M and Nuyttens JJ: Survival and prognostic factors of pulmonary oligometastases treated with stereotactic body radiotherapy. Acta Oncol, 2018, doi: 10.1080/028418 6X.2018.1521986. [Epub ahead of print]

4 Franzese C, Zucali PA, Di Brina L, D'Agostino G, Navarria P, Franceschini D, Santoro A and Scorsetti M: The efficacy of stereotactic body radiation therapy and the impact of systemic treatments in oligometastatic patients from prostate cancer. Cancer Med 7: 4379-4386, 2018.

5 Celik E, Semrau R, Baues C, Trommer-Nestler M, Baus W and Marnitz S: Robot-assisted extracranial stereotactic radiotherapy of adrenal metastases in oligometastatic non-small cell lung cancer. Anticancer Res 37: 5285-5291, 2017.

6 Buergy D, Rabe L, Siebenlist K, Stieler F, Fleckenstein J, Giordano FA, Wenz F and Boda-Heggemann J: Treatment of adrenal metastases with conventional or hypofractionated imageguided radiation therapy - patterns and outcomes. Anticancer Res 38: 4789-4796, 2018.

7 Hong JC, Ayala-Peacock DN, Lee J, Blackstock AW, Okunieff P, Sung MW, Weichselbaum RR, Kao J, Urbanic JJ, Milano MT, Chmura SJ and Salama JK: Classification for long-term survival in oligometastatic patients treated with ablative radiotherapy: A multi-institutional pooled analysis. PLoS One 13: e0195149, 2018.

8 Rades D, Huttenlocher S, Hornung D, Blanck O, Schild SE and Fischer D: Do patients with very few brain metastases from breast cancer benefit from whole-brain radiotherapy in addition to radiosurgery? Radiat Oncol 9: 267, 2014.

9 Rades D, Huttenlocher S, Rudat V, Hornung D, Blanck O, Phuong PC, Khoa MT, Schild SE and Fischer D: Radiosurgery with 20 Gy provides better local control of 1-3 brain metastases from breast cancer than with lower doses. Anticancer Res 35: 333-336, 2015.

10 Rades D, Dziggel L, Janssen S, Blanck O, Hornung D and Schild SE: A survival score for patients receiving stereotactic radiosurgery alone for brain metastases from breast cancer. Anticancer Res 36: 1073-1076, 2016.

11 Trovo M, Furlan C, Polesel J, Fiorica F, Arcangeli S, Giaj-Levra N, Alongi F, Del Conte A, Militello L, Muraro E, Martorelli D, Spazzapan S and Berretta M: Radical radiation therapy for oligometastatic breast cancer: Results of a prospective phase II trial. Radiother Oncol 126: 177-180, 2018.

12 Kwapisz D: Oligometastatic breast cancer. Breast Cancer, 2018. doi: 10.1007/s12282-018-0921-1. [Epub ahead of print]

13 Palma DA, Olson RA, Harrow S, Gaede S, Louie AV, Haasbeek C, Mulroy LA, Lock MI, Rodrigues G, Yaremko BP, Schellenberg D, Ahmad B, Griffioen G, Senthi S, Liu MC, Moore K, Currie S, Bauman GS, Warner A and Senan S: Stereotactic ablative radiation therapy for the comprehensive treatment of oligometastatic tumors (SABRCOMET): Results of a randomized trial. Int J Radiat Oncol Biol Phys 102: S3, 2018.

14 Rades D: Dose-fractionation schedules for radiotherapy of bone metastases. Breast Care (Basel) 5: 339-344, 2010.

15 Prasad D and Schiff D: Malignant spinal cord compression. Lancet Oncol 6: 15-24, 2005.

16 Rades D and Abrahm JL: The role of radiotherapy for metastatic epidural spinal cord compression. Nat Rev Clin Oncol 7: 590598, 2010.

17 Rades D, Veninga T, Stalpers LJA, Basic H, Rudat V, Karstens JH, Dunst J and Schild SE: Excellent outcome after radiotherapy alone for metastatic spinal cord compression (MSCC) in patients with oligometastases. J Clin Oncol 25: 50-56, 2007.

18 Rades D, Douglas S, Veninga T, Stalpers LJ, Bajrovic A, Rudat $\mathrm{V}$ and Schild SE: Prognostic factors in a series of 504 breast cancer patients with metastatic spinal cord compression. Strahlenther Onkol 188: 340-345, 2012.

19 Rades D, Douglas S and Schild SE: A validated survival score for breast cancer patients with metastatic spinal cord compression. Strahlenther Onkol 189: 41-46, 2013.

20 Janssen S, Bartscht T and Rades D: Prognosis of patients with metastatic spinal cord compression from adrenocortical carcinoma. In Vivo 30: 717-719, 2016.

21 Rades D, Douglas S, Veninga T and Schild SE: A validated survival score for patients with metastatic spinal cord compression from non-small cell lung cancer. BMC Cancer 12: 302, 2012.

22 Rades D, Douglas S, Veninga T, Bajrovic A, Stalpers LJ, Hoskin PJ, Rudat V and Schild SE: A survival score for patients with metastatic spinal cord compression from prostate cancer. Strahlenther Onkol 188: 802-806, 2012.

23 Bolm L, Janssen S, Bartscht T and Rades D: Radiotherapy alone for malignant spinal cord compression in young men with seminoma. Anticancer Res 36: 2033-2034, 2016. 
24 Rades D, Fehlauer F, Schulte R, Veninga T, Stalpers LJ, Basic H, Bajrovic A, Hoskin PJ, Tribius S, Wildfang I, Rudat V, Engenhart-Cabilic R, Karstens JH, Alberti W, Dunst J and Schild SE: Prognostic factors for local control and survival after radiotherapy of metastatic spinal cord compression. J Clin Oncol 24: 3388-3393, 2006.

25 Rades D, Stalpers LJA, Veninga T, Schulte R, Hoskin PJ, Obralic N, Bajrovic A, Rudat V, Schwarz R, Hulshof MC, Poortmans P and Schild SE: Evaluation of five radiation schedules and prognostic factors for metastatic spinal cord compression in a series of 1304 patients. J Clin Oncol 23: 3366-3375, 2005.

26 Joiner MC and Van der Kogel AJ: The linear-quadratic approach to fractionation and calculation of isoeffect relationships. In: Basic clinical radiobiology. Steel GG (ed.). New York, Oxford University Press, pp. 106-112, 1997.

27 Tomita T, Galicich JH and Sundaresan N: Radiation therapy for spinal epidural metastases with complete block. Acta Radiol Oncol 22: 135-143, 1983.

28 Kaplan E and Meier P: Nonparametric estimation from incomplete observation. J Am Stat Assoc 53: 457-481, 1958.
29 Rades D, Panzner A, Rudat V, Karstens JH and Schild SE: Dose escalation of radiotherapy for metastatic spinal cord compression (MSCC) in patients with relatively favorable survival prognosis. Strahlenther Onkol 187: 729-735, 2011

30 Patchell R, Tibbs PA, Regine WF, Payne R, Saris S, Kryscio RJ, Mohiuddin $M$ and Young B: Direct decompressive surgical resection in the treatment of spinal cord compression caused by metastatic cancer: a randomised trial. Lancet 366: 643-648, 2005.

31 Rades D, Douglas S, Veninga T, Stalpers LJ, Hoskin PJ, Bajrovic A, Adamietz IA, Basic H, Dunst J and Schild SE: Validation and simplification of a score predicting survival in patients irradiated for metastatic spinal cord compression. Cancer 116: 3670-3673, 2010 . 